\title{
Copper Containing Silicates as Catalysts for Liquid Phase Cyclohexane Oxidation
}

\author{
Rosenira S. da Cruz, ${ }^{a, b}$,Juliana M. de S. e Silva ${ }^{a}$,Ulrich Arnold ${ }^{a}$, Maurício S. Sercheli ${ }^{c}$ \\ and Ulf Schuchardt $* a$
}

\author{
${ }^{a}$ Instituto de Química, Universidade Estadual de Campinas, CP 6154, 13083-970, Campinas - SP, Brazil \\ ${ }^{b}$ Departamento de Ciências Exatas e Tecnológicas, Universidade Estadual de Santa Cruz, Rodovia Ilhéus - \\ Itabuna, km 16, 45650-000, Ilhéus - BA, Brazil \\ ${ }^{c}$ Instituto de Física Gleb Wataghin, Universidade Estadual de Campinas, 13083-970, Campinas - SP, Brazil
}

\begin{abstract}
Silicatos contendo cobre foram preparados pelo processo sol-gel catalisado por ácido. Os materiais foram caracterizados por difração e fluorescência de raios X, espectroscopia EPR, análise elementar, fisissorção de $\mathrm{N}_{2}$, termogravimetria, calorimetria diferencial de varredura, redução à temperatura programada, espectroscopia FTIR e UV/VIS. Os silicatos mostram-se catalisadores eficientes para a oxidação do cicloexano com hidroperóxido de tert-butila como oxidante e obtiveram-se cicloexanona e cicloexanol como produtos principais da reação. $\mathrm{O}$ metal mostrou-se fracamente ligado à matriz de sílica e foi observada lixiviação do metal para a fase líquida. A lixiviação foi quantificada por fluorescência de raios $X$. Testes de lixiviação mostraram que a atividade catalítica é devida às espécies de cobre suportadas. O cobre lixiviado não mostrou nenhuma atividade catalítica em fase homogênea.
\end{abstract}

Copper containing silicates have been prepared by an acid-catalyzed sol-gel process. The materials were characterized by X-ray diffraction and fluorescence, EPR spectroscopy, elemental analysis, $\mathrm{N}_{2}$-physisorption, thermogravimetry, differential scanning calorimetry, temperature-programmed reduction, FTIR and UV/VIS spectroscopy. The silicates were shown to be efficient catalysts for the oxidation of cyclohexane with tert-butyl hydroperoxide as oxidant. Cyclohexanol and cyclohexanone were obtained as the main products. The metal was shown to be weakly bound to the silicate matrix and metal leaching was observed. Leaching was quantified by X-ray fluorescence and leaching tests showed that the catalytic activity is due to supported copper species. Leached copper showed no activity in the homogeneous phase.

Keywords: sol-gel process, copper containing silicates, cyclohexane oxidation, tert-butyl hydroperoxide, leaching

\section{Introduction}

Considerable research effort has been spent during the last years on the development of new heterogeneous catalytic systems for the selective oxidation of hydrocarbons. In this context transition metal containing microand mesoporous materials, so-called redox molecular sieves, ${ }^{1}$ were extensively investigated. Besides a wide variety of crystalline zeolites, silicalites, aluminophosphates and silicoaluminophosphates, amorphous metallosilicates were found to be promising oxidation catalysts.

\footnotetext{
*e-mail: ulf@iqm.unicamp.br
}

Amorphous metallosilicates can be easily prepared via the sol-gel method. ${ }^{2}$ Compared to other preparation modes like impregnation, encapsulation or organometallic functionalization, the advantages of the sol-gel method are superior homogeneity of metal distribution, high surface areas, well defined pore size distributions, possibility to prepare multicomponent materials and control of surface polarity by choice of adequate precursors. ${ }^{3,4}$

The sol-gel method has been applied for the synthesis of various metallosilicates. Ti-aero- ${ }^{5}$ and xerogels ${ }^{6}$ have been synthesized and were shown to be active catalysts for the epoxidation of olefins with tert-butyl hydroperoxide. V-containing xerogels are active catalysts for a variety of oxidation reactions with $\mathrm{H}_{2} \mathrm{O}_{2}$, including 
epoxidation of alkenes, oxidation of secondary alcohols and hydroxylation of phenol. ${ }^{7}$ Co-xerogels have been reported to be efficient heterogeneous catalysts for the side-chain oxidation of alkyl arenes with anhydrous tertbutyl hydroperoxide. ${ }^{8}$ Furthermore, amorphous mesoporous silicates containing $\mathrm{W}$ and Mo have been prepared by the sol-gel method and have been shown to be active catalysts for the oxidation of alcohols and the epoxidation of alkenes with aqueous $\mathrm{H}_{2} \mathrm{O}_{2}{ }^{9}$ ?

Heterogeneous $\mathrm{Cu}$-catalysts are highly active in the reduction of $\mathrm{NO}$ and numerous catalysts, e.g. Cu oxides supported on alumina, silica, titania and zirconia as well as zeolite-based $\mathrm{Cu}$-catalysts have been reported. ${ }^{10}$ However their practical use for the elimination of NO in engine emissions is restricted because of their thermal instability and deactivation by steam. ${ }^{11}$ Copper compounds are also known to be active in the oxidation of alkanes and alkenes. Here we wish to report about the sol-gel synthesis of new $\mathrm{Cu}$-containing microporous silicates, their characterization and their use as heterogeneous catalysts for the oxidation of cyclohexane with tert-butyl hydroperoxide.

\section{Experimental}

\section{Synthesis of $\mathrm{Cu}-\mathrm{SiO}_{2}$}

The catalysts were prepared by an acid-catalyzed solgel process, ${ }^{12}$ using tetraethoxysilane $\mathrm{Si}(\mathrm{OEt})_{4}$ (TEOS) and copper(II) acetylacetonate $\left[\mathrm{Cu}(\mathrm{acac})_{2}\right]$ as precursors. Typically, a solution of $49 \mathrm{mmol}$ of TEOS (Aldrich, 98\%) and $1 \mathrm{mmol}$ of $\left[\mathrm{Cu}(\mathrm{acac})_{2}\right]$ (Aldrich, 97\%) in $150 \mathrm{mmol}$ of ethanol was placed in a $100 \mathrm{~mL}$ polypropylene beaker equipped with a magnetic stirring bar and $18 \mathrm{mmol}$ of aqueous $\mathrm{HCl}\left(8 \mathrm{~mol} \mathrm{~L}^{-1}\right)$ were added dropwise to the well stirred solution. The reaction mixture was stirred for $5 \mathrm{~min}$ and then allowed to stand at room temperature for 5 days, to remove the volatiles by slow evaporation. In order to obtain hydrophobic materials, $\mathrm{MeSi}(\mathrm{OEt})_{3}$ (MeTEOS; Aldrich 99\%) was also used as silicon precursor, thus obtaining $\mathrm{Cu}-\mathrm{MeSiO}_{2}$.

Usually, gel formation and solidification was complete after 5 days and the material was dried using one of the following procedures. Method A) the sample was heated from 303 to $338 \mathrm{~K}$ with a rate of $0.2 \mathrm{~K} \mathrm{~min}^{-1}$ and kept at this temperature for $5 \mathrm{~h}$. After further heating with a rate of $0.5 \mathrm{~K} \mathrm{~min}^{-1}$ the material was kept at $523 \mathrm{~K}$ for $5 \mathrm{~h}$. The material was slowly cooled down to room temperature with a cooling rate of $1 \mathrm{~K} \mathrm{~min}^{-1}$. Method B) The material was heated from 303 to $373 \mathrm{~K}$ with a rate of $15 \mathrm{~K} \mathrm{~min}^{-1}$. After $24 \mathrm{~h}$ at $373 \mathrm{~K}$ the silicate was further heated to $473 \mathrm{~K}$ with the same heating rate and kept at this temperature for $24 \mathrm{~h}$. After cooling to room temperature the glasses were crushed and sieved (100 mesh).

\section{Characterization of $\mathrm{Cu}-\mathrm{SiO}_{2}$ and $\mathrm{Cu}-\mathrm{MeSiO}_{2}$}

Powder X-ray diffraction was performed on a Shimadzu $\mathrm{XD}-3 \mathrm{~A}$ diffractometer, using $\mathrm{CuK} \alpha$ radiation and $2 \theta=5$ $50^{\circ}$. Copper contents were determined by X-ray fluorescence (XRF) on a Spectrace TX-5000 instrument, using calibration curves prepared from mixtures of $\mathrm{SiO}_{2}$ and $\mathrm{CuO}$. EPR spectra were measured at room temperature, using the $\mathrm{X}$ band $(9.7 \mathrm{GHz})$, in a Bruker $200 \mathrm{D}$ spectrometer. Elemental analyses were obtained on a Perkin Elmer 2400 instrument. Physisorption isotherms were measured at $77 \mathrm{~K}$ on a Micromeritics ASAP 2010 instrument with nitrogen as probe molecule. Prior to measurement the samples were heated to $523 \mathrm{~K}$ for $16 \mathrm{~h}$ under a flow of nitrogen. The Horvath-Kawazoe method ${ }^{13}$ was used to calculate pore size distributions from nitrogen adsorption isotherms. Surface areas were determined using the BET equation in the low pressure region $\left(\mathrm{p} / \mathrm{p}_{0}=0.200\right)$. Thermogravimetric analyses (TGA) were carried out under a flow of argon $\left(100 \mathrm{~mL} \mathrm{~min}^{-1}\right)$ on a DuPont 951 instrument with a heating rate of $10 \mathrm{~K} \mathrm{~min}^{-1}$ from 298 to $1273 \mathrm{~K}$. Differential scanning calorimetry analyses (DSC) were performed under the same conditions of the TGA experiments, using a DSC 2910 instrument. Temperatureprogrammed reduction analyses (TPR) were carried out in a homebuilt instrument, using an $\mathrm{H}_{2} / \mathrm{N}_{2}$ mixture (3 vol.\% $\mathrm{H}_{2}$ ) with a heating rate of $15 \mathrm{~K} \mathrm{~min}^{-1}$ up to $1023 \mathrm{~K}$. FTIR spectra were obtained on a Perkin Elmer 1600 instrument (optical resolution $4 \mathrm{~cm}^{-1}$ ) from $\mathrm{KBr}$ pellets containing $1 \%$ of the catalyst. UV/VIS spectra were recorded with a Perkin Elmer Lambda-9 series 1645 spectrometer, in the range of 200 to $1200 \mathrm{~nm}$, using the diffuse reflectance technique. Absorptions of the pure silicate without transition metal were measured in blank experiments and subtracted.

\section{Catalytic cyclohexane oxidation reactions}

Cyclohexane oxidation reactions were carried out in a three-necked flask, placed in a temperature equilibrated oil bath and fitted with a reflux condenser. Typically, a mixture of $95 \mathrm{mmol}$ of cyclohexane, $9.5 \mathrm{mmol}$ of tertbutyl hydroperoxide (TBHP, $82 \%$ in cyclohexane) and $100 \mathrm{mg}$ of $\mathrm{Cu}-\mathrm{SiO}_{2}\left(2.9 \times 10^{-5} \mathrm{~mol} \mathrm{Cu}\right)$ was magnetically stirred at $348 \mathrm{~K}$ for $24 \mathrm{~h}$. The reaction mixture was analyzed by gas chromatography (GC), taking aliquots at different reaction times. A Hewlett Packard HP 5890 gas chroma- 
tograph equipped with an Innowax 80/100 capillary column ( $25 \mathrm{~m}$ x $0.2 \mathrm{~mm}$ x $0.4 \mu \mathrm{m}$ film thickness) coupled to a flame ionization detector (FID) was used. Product quantification was carried out using 4-heptanone as internal standard and calibration curves obtained with authentic samples of cyclohexane, cyclohexanone and cyclohexanol. Results obtained in blank experiments without catalyst were subtracted. Since cyclohexyl hydroperoxide (CHHP) decomposes in part during chromatographic analysis, CHHP contents were determined by decomposition with $\mathrm{PPh}_{3}{ }^{14}$ and quantification of the additionally formed cyclohexanol by GC. By-products were identified by GC using the same instrument and an HP 5979 mass selective detector (MSD). The formation of acids was investigated by esterification of the reaction mixture with methanol and identification of the products by GC-MSD. Consumption of TBHP was determined after the reaction by iodometric titration. ${ }^{15}$

\section{Leaching and recycling tests}

In leaching tests the catalyst was separated from the reaction mixture after $4 \mathrm{~h}$ by filtration at the reaction temperature. ${ }^{16}$ Another portion of 9.5 mmol of oxidant was added and the reaction mixture was allowed to react further in the absence of the catalyst. The catalyst was used i) without pre-treatment, ii) pre-treated by $18 \mathrm{~h}$ soxhlet extraction with acetonitrile followed by $4 \mathrm{~h}$ drying at 393 $\mathrm{K}$ and iii) pre-treated by $2 \mathrm{~h}$ calcination at $723 \mathrm{~K}$ under a flow of air $\left(40 \mathrm{~mL} \mathrm{~min} \mathrm{~m}^{-1}\right)$ followed by soxhlet extraction with acetonitrile. The reaction solution was analyzed by GC immediately after removal of the catalyst and after the total reaction time of $24 \mathrm{~h}$. The $\mathrm{Cu}$ content in the catalyst was determined by XRF before and after the catalytic reaction.

Recycling tests with repeated use of $\mathrm{Cu}-\mathrm{SiO}_{2}$ in 5 consecutive reactions were carried out. The catalyst was removed from the reaction mixture after $24 \mathrm{~h}$ by filtration, washed with acetone, dried at $393 \mathrm{~K}$ for $6 \mathrm{~h}$ and subjected to the next catalytic run, using the same substrate:oxidant: catalyst molar ratio.

\section{Results and Discussion}

Synthesis and characterization of $\mathrm{Cu}-\mathrm{SiO}_{2}$ and $\mathrm{Cu}-\mathrm{MeSiO}_{2}$

The colour of copper(II) acetylacetonate dissolved in EtOH/TEOS changed from blue to yellow during the addition of $\mathrm{HCl}$ and remained yellow during the sol-gel process. After thermal treatment clear green glasses were obtained. Some physico-chemical properties of the materials are summarized in Table 1.

Elemental analyses showed that the metal contents in the catalysts are lower than the values $(\sim 2 \mathrm{wt} . \%)$ expected from the gel compositions. Since there is no washing of the catalysts in the preparation process, which could cause a loss of metal, the lower values can only be explained by the volatility of the metal precursor. ${ }^{17,18}$ The observed carbon and hydrogen contents are probably due to incorporation of alkoxide ligands, acetylacetonate and EtOH into the silicate matrix as well as re-alkoxylation of surface $\mathrm{OH}$ groups. The $\mathrm{C} / \mathrm{H}$-content of the material prepared with a molar ratio MeTEOS:TEOS of 4:1 indicates the presence of methyl groups in the final material. Assuming that the $\mathrm{Si}-\mathrm{C}$ bond is not cleaved during material preparation, a content of approximately $11 \mathrm{mmol}$ methyl groups per $\mathrm{g}$ of $\mathrm{Cu}-\mathrm{MeSiO}_{2}$ is calculated based on the carbon content of $\mathrm{Cu}-\mathrm{SiO}_{2}$.

From $\mathrm{N}_{2}$-physisorption isotherms monomodal narrow pore size distributions and high surface areas were calculated (Table 1). It can be seen from Table 1 that the pore size diameter is only slightly influenced by the heating rate. It is expected that a slower evaporation of ethanol and water gives rise to large pore diameters, ${ }^{19}$ however, we only observed a very small dependence of the pore diameter on the heating rate. Partial substitution of $\mathrm{Si}-\mathrm{OH}$ groups by $\mathrm{SiCH}_{3}$ functions also results in a small increase in pore diameter. Since the drying process only

Table 1. Physico-chemical properties of the materials

\begin{tabular}{|c|c|c|c|c|c|}
\hline \multirow[t]{2}{*}{ Material } & \multicolumn{3}{|c|}{ Elemental analysis (wt.\%) } & \multirow[t]{2}{*}{ BET surface $\left(\mathrm{m}^{2} \mathrm{~g}^{-1}\right)$} & \multirow[t]{2}{*}{ Pore diameter $^{\mathrm{a}}(\mathrm{nm})$} \\
\hline & $\mathbf{C u}$ & C & $\mathbf{H}$ & & \\
\hline $\mathrm{SiO}_{2}^{\mathrm{b}}$ & - & 1.8 & 2.7 & 364 & 0.65 \\
\hline $\mathrm{Cu}-\mathrm{SiO}_{2}{ }^{\mathrm{b}}$ & $1.80 \pm 0.04$ & 2.9 & 3.6 & 424 & 0.69 \\
\hline $\mathrm{Cu}-\mathrm{SiO}_{2}{ }^{\mathrm{c}}$ & $1.82 \pm 0.04$ & 2.4 & 3.1 & 392 & 0.66 \\
\hline $\mathrm{Cu}-\mathrm{MeSiO}_{2}{ }^{\mathrm{c}, \mathrm{d}}$ & $1.58 \pm 0.04$ & 15.4 & 4.2 & 555 & 0.72 \\
\hline
\end{tabular}

a Determined by the Horvath-Kawazoe method

${ }^{b}$ Drying method A

'Drying method B

${ }^{\mathrm{d}}$ Material prepared using a molar ratio MeTEOS:TEOS of 4:1 
slightly affects the characteristics of the materials, only those materials, which were dried with the faster heating rate (method $\mathrm{B})$, were further investigated.

TGA analyses of $\mathrm{Cu}-\mathrm{SiO}_{2}$ showed a weight loss of about $5 \%$ up to $393 \mathrm{~K}$, which can be attributed to the loss of water and ethanol. The modified silicate $\mathrm{Cu}-\mathrm{MeSiO}_{2}$ showed no weight loss in this temperature range, in agreement with the expected hydrophobic nature of the material. The weight loss of both materials at temperatures above $573 \mathrm{~K}$ is attributable to organic impurities, indicating incomplete polycondensation ${ }^{20}$ and the dehydroxylation of the surface. ${ }^{21}$

The DSC measurements for $\mathrm{Cu}-\mathrm{SiO}_{2}$, shown in Figure 1 , are compatible with the TGA results and an endothermic peak due to the loss of water and ethanol is observed at $394 \mathrm{~K}$. An exothermic peak at $698 \mathrm{~K}$ is typical of the combustion of organic impurities. A second endothermic peak at about $1133 \mathrm{~K}$ can be ascribed to the dehydroxylation of the surface and/or to the transition from amorphous to crystalline state. The methylated compound $\mathrm{Cu}-\mathrm{MeSiO}_{2}$ shows only a broad exothermic peak around $743 \mathrm{~K}$, attributable to the combustion of organic residues and functional groups.

The FTIR spectra of $\mathrm{Cu}-\mathrm{SiO}_{2}$ and $\mathrm{Cu}-\mathrm{MeSiO}_{2}$ (Figure 2) show the typical silicate absorptions at about 1085 (with a shoulder around $\left.1200 \mathrm{~cm}^{-1}\right), 800,550$ and $450 \mathrm{~cm}^{-1}$ attributable to $\mathrm{Si}-\mathrm{O}-\mathrm{Si}$ bending and stretching vibrations. The shift of the band at $1085 \mathrm{~cm}^{-1}$ to lower wavenumbers compared to the metal-free silicate indicates the incorporation of metal oxide and the formation of Si-O-M bonds. ${ }^{22}$ For $\mathrm{Cu}-\mathrm{MeSiO}_{2}$ this band is splitted into two absorptions and the shoulder disappears. Both materials show a broad band at about $3700 \mathrm{~cm}^{-1}$ and a band at $1630 \mathrm{~cm}^{-1}$. The former is due to surface hydroxyl groups and adsorbed water, the

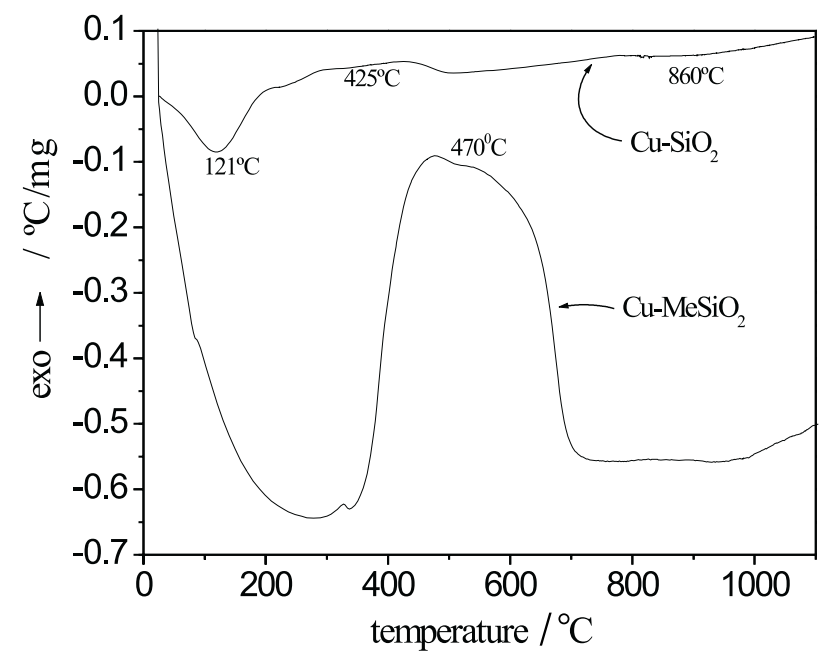

Figure 1. DSC curves of $\mathrm{Cu}-\mathrm{SiO}_{2}$ and $\mathrm{Cu}-\mathrm{MeSiO}_{2}$ latter can be assigned to water. For the hydrophobic $\mathrm{Cu}$ $\mathrm{MeSiO}_{2}$ these bands are, as expected, less intensive compared to $\mathrm{Cu}-\mathrm{SiO}_{2}$. Typical absorptions of $\mathrm{Cu}-\mathrm{MeSiO}_{2}$ appear between 2985 and $2975 \mathrm{~cm}^{-1}$ and at $1276 \mathrm{~cm}^{-1}$. The bands are due to the $\mathrm{Si}_{-} \mathrm{CH}_{3}$ groups and can be attributed to $\mathrm{C}-\mathrm{H}$ and $\mathrm{Si}-\mathrm{C}$ stretching vibrations. Very weak absorptions of $\mathrm{Cu}-\mathrm{SiO}_{2}$ in the range between 2985 and $2975 \mathrm{~cm}^{-1}$ indicate the presence of $\mathrm{C}-\mathrm{H}$ bonds and suggest incomplete polycondensation and/or incorporation of ethanol. An absorption at $955 \mathrm{~cm}^{-1}$ was observed for $\mathrm{Cu}-\mathrm{SiO}_{2}$, which can be ascribed to surface $\mathrm{Si}-\mathrm{OH}$ vibrations ${ }^{23}$ and possibly superposes absorptions of Si-O-Cu bonds. The intensity of this band is taken as indication of heterogeneity in mixed oxides. ${ }^{24}$ However, since the metal content in $\mathrm{Cu}-\mathrm{SiO}_{2}$ is low, this method is not applicable. Nevertheless, the shift of this band from $946 \mathrm{~cm}^{-1}$ in the metal-free silicate to $955 \mathrm{~cm}^{-1}$ in $\mathrm{Cu}-\mathrm{SiO}_{2}$ suggests that there is a partial contribution of $\mathrm{Si}-\mathrm{O}-\mathrm{Cu}$ bonds. For the methylated $\mathrm{Cu}-\mathrm{MeSiO}_{2}$ this absorption occurs only as a weak shoulder. Remarkably, the typical absorptions of the acetylacetonate ligand at 1528 and $1380 \mathrm{~cm}^{-1}$ are not observed for the silicate, indicating that most of the ligand was separated from the metal during the sol-gel procedure.

The diffuse reflectance UV/VIS spectra of [Cu(acac $\left.)_{2}\right]$, $\mathrm{Cu}-\mathrm{SiO}_{2}, \mathrm{Cu}-\mathrm{MeSiO}_{2}$ and mixtures of $\mathrm{CuO}$ and $\mathrm{SiO}_{2}$ are shown in Figure 3. The spectra of $\mathrm{Cu}-\mathrm{SiO}_{2}$ and $\mathrm{Cu}-\mathrm{MeSiO}_{2}$ are very similar but completely different from those of the acetylacetonate precursor and the mixture of $\mathrm{CuO}$ and $\mathrm{SiO}_{2}$. The $\mathrm{Cu}$-silicates exhibit broad absorptions between 210 and $300 \mathrm{~nm}$ with shoulders at about $350 \mathrm{~nm}$. These

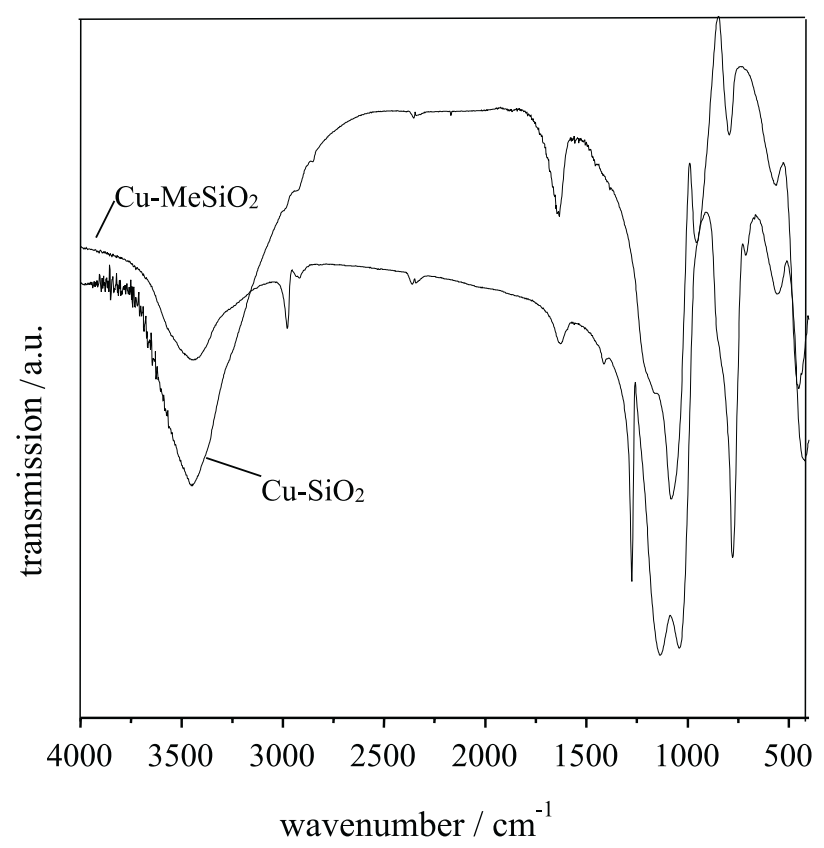

Figure 2. IR spectra of $\mathrm{Cu}-\mathrm{SiO}_{2}$ and $\mathrm{Cu}-\mathrm{MeSiO}_{2}$ 


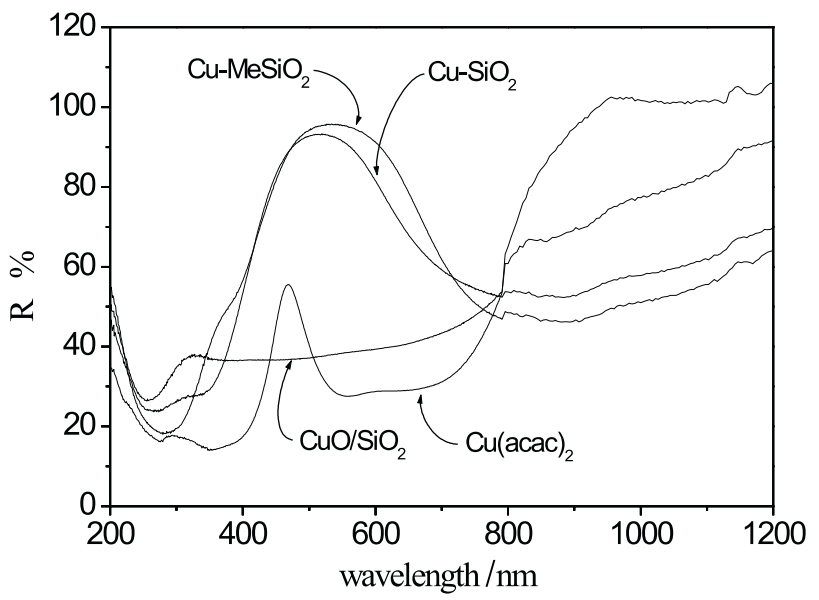

Figure 3. UV/VIS spectra of $\mathrm{Cu}-\mathrm{SiO}_{2}, \mathrm{Cu}-\mathrm{MeSiO}_{2},\left[\mathrm{Cu}(\mathrm{acac})_{2}\right]$ and a mixture of $\mathrm{CuO}$ and $\mathrm{SiO}_{2}$

absorptions can be assigned to $\mathrm{Cu}^{2+} \leftarrow \mathrm{O}^{2-}$ charge transfers. Broad bands between 800 and $1200 \mathrm{~nm}$ are typical of d-d transitions of $\mathrm{Cu}^{2+}$ in an octahedral or square pyramidal environment. ${ }^{25}$ However, these bands are too broad to allow a detailed assignment of the absorptions.

The EPR spectra of the $\mathrm{Cu}-\mathrm{SiO}_{2}$ and $\mathrm{Cu}-\mathrm{MeSiO}_{2}$ show the presence of only one $\mathrm{Cu}^{2+}$ species with a single signal at $g=2.18$. The spectra of $\mathrm{Cu}-\mathrm{SiO}_{2}$ and $\mathrm{Cu}-\mathrm{SiO}_{2}$ treated by $18 \mathrm{~h}$ soxhlet extraction with acetonitrile are given in Figure 4. It can be seen that the signal intensity of the extracted catalyst is remarkably reduced, thus indicating removal of $\mathrm{Cu}$ by soxhlet extraction.

Powder XRD analyses confirm the amorphous nature of the silicates. No crystalline $\mathrm{CuO}$ phase was detected. However, after $4 \mathrm{~h}$ calcination at $873 \mathrm{~K}$ under a flow of air, the X-ray diffraction patterns of $\mathrm{CuO}$ were observed and the colour of the samples turned from green to grey. This

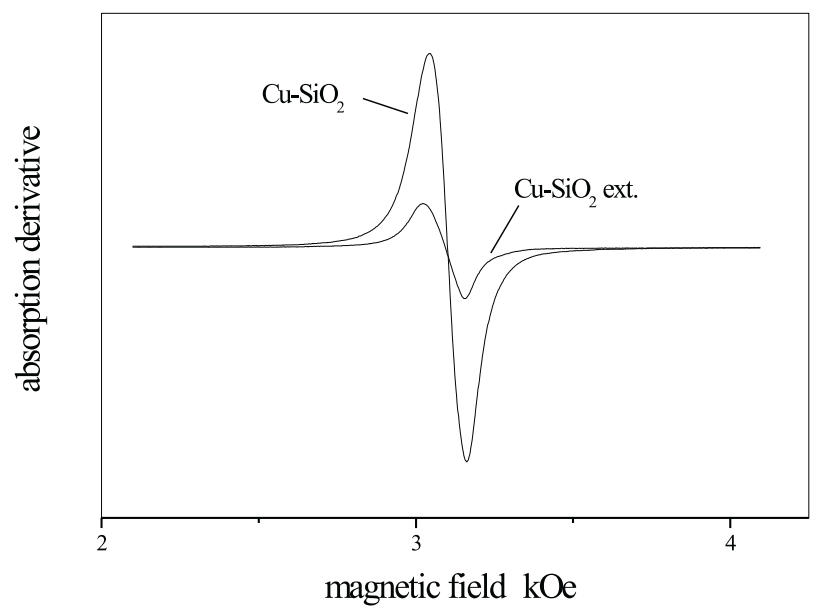

Figure 4. EPR spectra of $\mathrm{Cu}-\mathrm{SiO}_{2}$ before and after soxhlet extraction with acetonitrile can be explained by agglomeration of the $\mathrm{CuO}$ on the surface of the silica to form larger particles. Furthermore, TPR experiments showed a reduction peak at $423 \mathrm{~K}$, thus suggesting that copper is attached to the silicate surfaces as oxide species. No evidence for copper incorporation in the silicate framework has been obtained from these analysis techniques.

\section{Catalytic cyclohexane oxidation}

Cyclohexane conversion and product distribution in the $\mathrm{Cu}-\mathrm{SiO}_{2}$-catalyzed cyclohexane oxidation is given in Figure 5 as a function of time. Cyclohexane conversion was $4.4 \%$ after $24 \mathrm{~h}$ with $84 \%$ selectivity for cyclohexanone and cyclohexanol. The formation of cyclohexanol is favoured in the beginning of the reaction, reaching a maximum concentration after about $7 \mathrm{~h}$. The subsequent decrease in cyclohexanol concentration is linked to a distinct increase in cyclohexanone concentration, thus suggesting over-oxidation of cyclohexanol. Cyclohexyl hydroperoxide (CHHP) shows a low concentration and other products, in particular adipic acid, were detected with longer reaction times. Experiments where cyclohexanol was added to the reaction mixture in the beginning of the reaction showed that the formation of cyclohexanone is favoured. On the other hand, addition of cyclohexanone to the reaction mixture lowered cyclohexane conversion by approximately $50 \%$.

Catalyst recycling experiments were carried out with repeated use of $\mathrm{Cu}-\mathrm{SiO}_{2}$ in the oxidation of cyclohexane. The results of 5 consecutive catalytic reactions are given

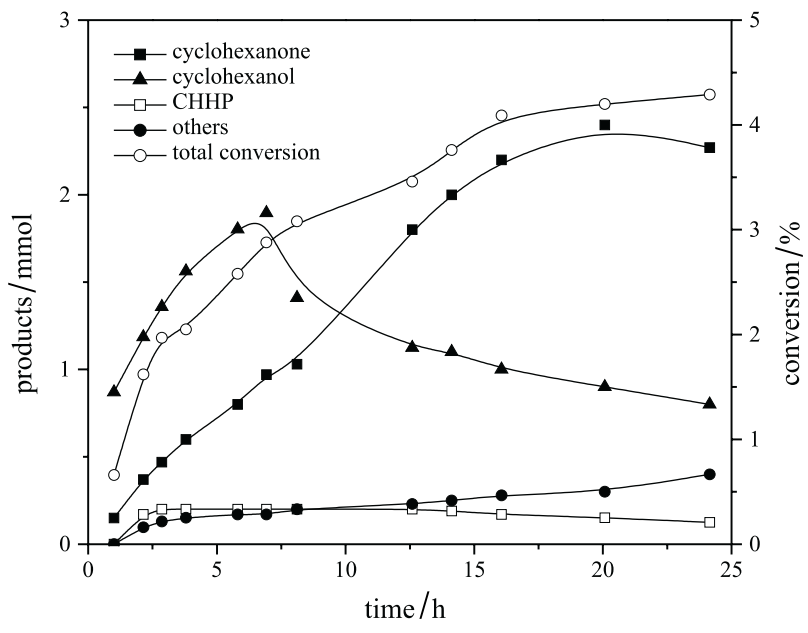

Figure 5. Time dependence of product distribution and cyclohexane conversion in the $\mathrm{Cu}-\mathrm{SiO}_{2}$-catalyzed oxidation of cyclohexane. Reaction conditions: $95 \mathrm{mmol}$ cyclohexane, $9.5 \mathrm{mmol}$ TBHP $(82 \%$ in cyclohexane) and $100 \mathrm{mg}$ of $\mathrm{Cu}-\mathrm{SiO}_{2}\left(2.9 \times 10^{-5} \mathrm{~mol} \mathrm{Cu}\right) ; 348 \mathrm{~K}$. Results obtained in blank experiments without catalyst are already subtracted 
in Figure 6. It can be seen that cyclohexane conversion decreases significantly from the first to the third catalytic run but reduces only slightly after this. Simultaneously, the $\mathrm{Cu}$ content decreases from 1.82 in the first to $0.49 \%$ in the fifth run. The decrease in conversion during the first reactions suggests a loss of copper probably by the removal of weakly bound copper species.

Catalyst metal contents after pre-treatment and after the catalytic reactions as well as cyclohexanone yields obtained in the leaching tests are summarized in Table 2. It can be seen that pre-treatment by soxhlet extraction reduces the $\mathrm{Cu}$ content in $\mathrm{Cu}-\mathrm{SiO}_{2}$ from 1.82 to $0.92 \%$ and calcination followed by soxhlet extraction yields a catalyst with a reduced $\mathrm{Cu}$ content of $1.26 \%$. The loss of metal is much more drastic for $\mathrm{Cu}-\mathrm{MeSiO}_{2}$ where extraction with acetonitrile reduces the metal content from 1.58 to $0.25 \%$. These results show that $\mathrm{Cu}$ species can easily be removed from the catalysts. Calcination seems to stabilize $\mathrm{Cu}-\mathrm{SiO}_{2}$, since the loss of copper is lower compared to the material treated only by soxhlet extraction. The pre-treated catalysts

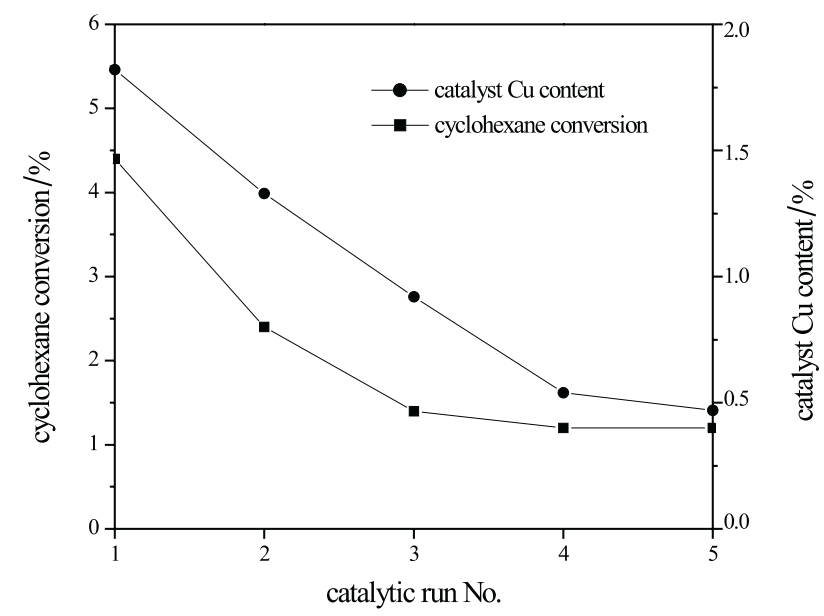

Figure 6. Catalyst recycling tests. Cyclohexane conversions in 5 consecutive reactions with re-use of $\mathrm{Cu}-\mathrm{SiO}_{2}$ show further loss of copper in the catalytic reactions (Table 2, entries 2, 3 and 5). Facile leaching can be explained by weakly bound surface copper species, which are not fixed in the catalyst matrix. These results are in agreement with the properties of other $\mathrm{Cu}$-containing heterogeneous catalysts, e.g. those of $\mathrm{Cu}$-containing zeolites..$^{10}$ However, despite of extensive metal leaching into the homogeneous phase, catalytic cyclohexanone formation stops after removal of the silicates from the reaction mixtures. As it can be seen from Table 2, cyclohexanone concentration increases only slightly with prolonged reaction times due to the non-catalyzed reaction. These results indicate that the reaction is catalyzed by supported heterogeneous copper species and that the leached species are not active in cyclohexane oxidation, probably due to complexation by the carboxylic acids formed during the oxidations.

\section{Conclusions}

Copper containing silicates can be prepared by a simple acid-catalyzed sol-gel process. From several analysis techniques one can conclude that the metal is attached to the surface of the silicate and not homogeneously dispersed into its framework. Using $\mathrm{MeSi}(\mathrm{OEt})_{3}$ as silicon precursor hydrophobic materials with methylated surfaces can be obtained. The metal can easily be removed from the catalysts, especially the methylated ones, by soxhlet extraction with acetonitrile, indicating weakly bound $\mathrm{Cu}$ species. $\mathrm{Cu}-\mathrm{SiO}_{2}$ is an active and selective catalyst for the oxidation of cyclohexane to cyclohexanol and cyclohexanone. Cyclohexanol is further oxidized to cyclohexanone. Catalyst recycling experiments show that the catalyst can be used repeatedly but a significant decrease in cyclohexane conversion is observed. Leaching tests show an extensive leaching. However, dissolved copper species exhibit no catalytic activity in the homogeneous phase, showing that the catalytic activity is due to heterogeneous copper species.

Table 2. Leaching tests in the oxidation of cyclohexane catalyzed by $\mathrm{Cu}$-containing silicates ${ }^{\mathrm{a}}$

\begin{tabular}{|c|c|c|c|c|c|}
\hline \multirow[t]{2}{*}{ No. } & \multirow[t]{2}{*}{ Catalyst } & \multicolumn{2}{|c|}{ Cyclohexanone $^{\mathrm{b}}(\mathrm{mmol})$} & \multirow[t]{2}{*}{ Initial $\mathrm{Cu}$ content $(\%)$} & \multirow[t]{2}{*}{ Final $\mathrm{Cu}$ content $(\%)$} \\
\hline & & $4 \mathrm{~h}$ & $24 \mathrm{~h}$ & & \\
\hline 1 & $\mathrm{Cu}-\mathrm{SiO}_{2}$ & 1.47 & 1.59 & $1.82 \pm 0.04$ & $1.33 \pm 0.04$ \\
\hline 2 & $\mathrm{Cu}-\mathrm{SiO}_{2}$ ext. $^{\mathrm{c}}$ & 0.12 & 0.17 & $0.92 \pm 0.04$ & $0.54 \pm 0.04$ \\
\hline 3 & $\mathrm{Cu}-\mathrm{SiO}_{2}$ calc./ext. $^{\mathrm{d}}$ & 0.14 & 0.21 & $1.26 \pm 0.04$ & $1.09 \pm 0.04$ \\
\hline 4 & $\mathrm{Cu}-\mathrm{MeSiO}_{2}$ & 1.39 & 1.49 & $1.58 \pm 0.04$ & $0.23 \pm 0.04$ \\
\hline 5 & $\mathrm{Cu}-\mathrm{MeSiO}_{2}^{2}$ ext. $^{\mathrm{c}}$ & 0.10 & 0.12 & $0.25 \pm 0.04$ & $0.18 \pm 0.04$ \\
\hline
\end{tabular}

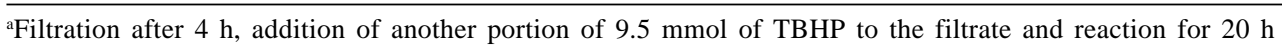

${ }^{b}$ Results obtained in blank experiments without catalyst are already subtracted

${ }^{\mathrm{c} S}$ Soxhlet extraction with acetonitrile for $18 \mathrm{~h}$ followed by drying at $393 \mathrm{~K}$ for $4 \mathrm{~h}$

${ }^{\mathrm{d}}$ Calcination under a flow of air $\left(40 \mathrm{~mL} \mathrm{~min}^{-1}\right)$ at $723 \mathrm{~K}$ for $2 \mathrm{~h}$ followed by soxhlet extraction with acetonitrile 


\section{Acknowledgements}

This work was supported by the Fundação de Amparo à Pesquisa do Estado de São Paulo (FAPESP). Fellowships from FAPESP and the Conselho Nacional de Desenvolvimento Científico e Tecnológico (CNPq) are gratefully acknowledged. U. A. thanks FAPESP and the Deutscher Akademischer Austauschdienst (DAAD) for a scientific exchange grant within a FAPESP-DAAD cooperation. The authors are grateful to Nitrocarbono S.A. for gifts of cyclohexane and tert-butyl hydroperoxide.

\section{References}

1. Arends, I. W. C. E.; Sheldon, R. A.; Wallau, M.; Schuchardt, U.; Angew. Chem. Int. Ed. Engl. 1997, 36, 1143.

2. Baiker, A.; Stud. Surf. Sci. Catal. 1996, 101, 51.

3. Gomez, R.; Gonzalez, R. D.; Lopez, T.; Catal. Today 1997, 35, 293.

4. Rodríguez-Isquierdo, J. M.; Cauqui, M. A.; J. Non-Cryst. Solids 1992, 147, 724 .

5. Hutter, R.; Mallat, T.; Baiker, A.; J. Catal. 1995, 153, 177.

6. Maier, W. F.; Martens, J. A.; Klein, S.; Heilmann, J.; Parton, R.; Vercruysse, K.; Jacobs, P. A.; Angew. Chem. Int. Ed. Engl. 1996, 35, 180.

7. Neumann, R.; Levin-Elad, M.; Appl. Catal. A: Gen. 1995, 122, 85 .

8. Rogovin, M.; Neumann, R.; J. Mol. Cat. A: Chem. 1999, 138, 315.

9. Neumann, R.; Levin-Elad, M.; J. Catal. 1997, 166, 206.

10. Centi, G.; Perathoner, S.; Appl. Catal. A: Gen. 1995, 132, 179.
11. Shelef, M.; Chem. Rev. 1995, 95, 209.

12. Klein, S.; Thorimbert, S.; Maier, W. F.; J. Catal. 1996, 163, 476.

13. Horvath, G.; Kawazoe, K.; J. Chem. Eng. Jpn. 1983, 16, 470.

14. Jacobs, P. A.; Rouxhet, P. G.; Genet, M. I.; De Vos, D. E.; Vannopen, D. L.; Angew. Chem. Int. Ed. Engl. 1995, 34, 560.

15. Baccan, N.; Andrade, J. C.; Godinho, O. E. S.; Barone, J. S.; Química Analítica Quantitativa Elementar, 2nd ed., Edgard Blücher Ltda: São Paulo, 1985, p 201.

16. Sheldon, R. A.; Wallau, M.; Arends, I. W. C. E.; Schuchardt, U.; Acc. Chem. Res. 1998, 31, 485.

17. Lambert, C. K.; Gonzalez, R. D.; Appl. Catal. A: Gen. 1998, 172, 233.

18. Sheldon, R. A.; Babich, I. V.; Plyuto, Y. V.; Appl. Surf. Sci. 1999, 140, 176.

19. Scherer, G. W.; J. Non-Cryst. Solids 1988, 100, 77.

20. Móran-Pineda, M.; Castillo, S.; López, T.; Gómez, R.; Novaro, O.; Appl. Catal. B: Environ. 1999, 21, 79.

21. Nassar, E. J.; Neri, C. R.; Calefi, P. S.; Serra, O. A.; J. NonCryst. Solids 1999, 247, 124.

22. Zeng, H. C.; Zhan, Z.; J. Non-Cryst. Solids 1999, 243, 26.

23. Neumann, R.; Levin-Elad, M.; J. Catal. 1997, 166, 206.

24. Miller, S. C.; Fujino, M.; Ko, E. I.; J. Catal. 1994, 148, 673.

25. Praliaud, H.; Mikhailenko, S.; Chajar, Z.; Primet, M.; Appl. Catal. B: Environ. 1998, 16, 359.

Received: February 19, 2001

Published on the web: January 28, 2002

FAPESP helped in meeting the publication costs of this article. 